\title{
Pelatihan Merancang Bisnis Online di Masa Pandemi bagi Mahasiswa
}

\author{
Muhammad Rakib ${ }^{1}$, Agus Syam², Marhawati ${ }^{3}$, Hajar Dewantara ${ }^{4}$ \\ 1,2,3,4 Jurusan Bisnis dan Kewirausahaan, Fakultas Ekonomi, Universitas Negeri Makassar
}

\begin{abstract}
Abstrak. Mitra dalam Program Kemitraan Masyarakat (PKM) ini adalah Kelompok Mahasiswa Wirausaha Muda di Kota Makassar. Masalahnya adalah mitra belum memiliki keterampilan memadai dalam mengoptimalkan pemanfaatan internet dan media sosial sebagai media bisnis online dan belum memiliki pemahaman yang memadai mengenai legalitas dalam bertransaksi online. Metode yang digunakan adalah: observasi, testing, pelatihan dan pembinaan, serta evaluasi. Hasil yang dicapai adalah peserta memiliki tingkat berpartisipasi sangat tinggi dalam pelatihan merancang bisnis online di tengah pandemi, memiliki keterampilan sangat memadai dalam memanfaatkan internet dan media sosial sebagai media bisnis online dan memiliki pemahaman tentang legalitas bisnis online.
\end{abstract}

Kata kunci: Pelatihan Bisnis Online, Media Sosial, E-Commerce

Abstract. The Partners of this Community Partnership Program (PKM) are the Young Entrepreneur Student Group in Makassar City. The problem is that partners do not have adequate skills in optimizing the use of the internet and social media as online business media and do not have adequate understanding of the legality of online transactions. The methods used are: observation, testing, training and coaching, and evaluation. The results achieved were participants had a very high level of participation in training in designing online businesses in the midst of a pandemic, had very adequate skills in utilizing the internet and social media as online business media and had an understanding of the legality of online business.

Keywords: Online Business Training, Social Media, E-Commerce

\section{PENDAHULUAN}

Perkembangan teknologi komunikasi dan cepatnya arus informasi menyebabkan terjadinya perubahan kultur budaya dan aktivitas keseharian masyarakat. Era yang saat ini dijuluki era information age ini, media elektronik sudah menjadi kebutuhan primer yang menjadi tumpuan masyarakat dalam menjalankan segala aktivitas termasuk kegiatan perekonomian. Bisnis merupakan salah satu roda penggerak perekonomian negara saat ini tak luput dari ketergantungan terhadap pesatnya arus informasi. Aktfivitas perekonomian saat ini dipaksa untuk beradaptasi dengan perkembangan teknologi. Tiap negara harus siap, jika tidak ingin tertinggal atau tergerus oleh zaman.

Kegiatan bisnis konvensional yang beberapa tahun terakhir menjadi tombak penggerak pertumbuhan ekonomi negara, kini harus segera bertransformasi ke mode bisnis berbasis Teknologi dan informasi atau yang lazim disebut Bisnis Online. Bisnis online merupakan sistem atau kegiatan bisnis yang dijalankan dengan mengandalkan internet sebagai media pemasaran. Penjualan secara online atau Bisnis Online memiliki kelebihan yang banyak daripada penjualan secara konvensional. Terlebih di masa Pandemi Covid-19 ini, hampir seluruh aktivitas diluar rumah dihentikan sejenak. Semua aktivitas vital dialihkan serta diupayakan dilaksanakan secara virtual, termasuk aktivitas perekonomian.

Para pelaku UKM khususnya saat ini dipaksa untuk berimprovisasi dengan keadaan. UKM serta pegiat Start-Up saat ini dituntut untuk kreatif dan inovatif dalam memanfaatkan teknologi agar tetap bisa bertahan di tengah pandemi ini. Sehingga IT dan Penguasaan IT saat ini menjadi hal yang wajib dan krusial bagi para pelaku bisnis, dan untuk pengembangan usaha di masa yang akan datang. 
Pada kondisi pandemi saat ini, menjalan bisnis secara online sangat tepat. Selain karena keterbatasan kontak fisik secara langsung, bisnis secara online akan memudahkan pemasaran produk dan transaksi jual-beli tetap bisa berjalan tanpa kontak langsung antara pembeli dan penjual. Keberadaan Social Media menjadi peluang besar bagi para pelaku UKM dan bisnis Statup dalam mengembangkan bisnis mereka serta tetap mampu bertahan meski kondisi pandemi. Media Sosial beserta platform E-commerce saat ini banyak bermunculan dan membuka peluang bagi para pebisnis, khususnya pebisnis muda dan millenials dalam mengembangkan usaha. Keberadaan teknologi beserta fitur media informasi di dalamnya menjadi alasan banyaknya pebisnis muda. Melihat perkembangan zaman yang canggih serta kehidupan manusia yang semakin praktis, pelaku usaha harus segara beralih ke sistem penjualan yang berbasi teknologi.

Keberadaan akses internet saat ini menyebabkan batasan-batasan informasi sudah tidak ada lagi. Aktivitas dunia nyata perlahan berkurang dan beralih ke dunia virtual atau maya. Di dunia maya, setiap pribadi memiliki hak yang sama untuk memberikan dan mendapatkan informasi tanpa batasan dan penghalang. Globalisasi yang sempurna sebenarnya telah terjadi di dunia maya, karenanya setiap komunitas digital dapat terhubung satu sama lain. Implikasi dari perkembangan teknologi dan informasi saat ini melahirkan inovasi dalam beberapa aktivitas vital keseharian masyarakat, seperti e-business, e-commerce, elearning, e-book, e-Money, Mobile Banking, eBanking, dan lain sebagianya (Aco and Endang 2017). Bisnis Online adalah kegiatan-kegiatan bisnis yang terkait dengan aktivitas konsumen (consumers), manufaktur (manufaktures), service providers dan pedagang perantara (intermediaries), dengan menggunakan jaringan-jaringan komputer (computer networks) yaitu internet (Ardianti, Wardiani, and Adnani, 2016)

Definsi global tentang Bisnis Online adalah semua bentuk transaksi perdgangan barang atau jasa yang dilakukan secara elektronik (Atsiska dkk, 2019). Melalui bisnis online akan terjadi hubungan yang lebih cepat, intensif, dengan penggunaan biaya yang lebih efisien antara pelaku usaha dengan para stakeholdernya (Djamaludin, Aviasti, and Rukmana, 2016). Beberapa aktivitas bisnis yang dapat dilakukan dengan melalui bisnis online seperti, kegiatan pemasaran, promosi, transaksi, pembayaran, maupun kegiatan lainnya yang memerlukan inovasi dan pengembangan mengandalkan jaringan internet (Farell, Thamrin, and Novid, 2019).

Bagi para pelaku bisnis muda dan pemula, memulai bisnis secara online khususnya dalam pemasaran perlu mempertimbangkan beberapa hal diantaranya, ketersediaan teknologi (gadget/smartphone/ Laptop) (Rakib, 2015), memanfaatkan Social Media yang umum digunakan, pengalaman serta kemampuan IT. Social Media memiliki potensi menghubungkan banyak orang dengan mudah dan gratis. Sehingga, social media kini menjadi trend dalam kegiatan bisnis. Menurut (Kaplan and Haenlein 2010). Social Media merupakan sekolompok aplikasi berbasiskan internet yang dibangun berdasarkan kerangka pikiran ideologi dan teknologi dari web 2.0, dan memungkinkan terciptanya sistem pertukaran informasi diantara pengguna internet (Delerue, Kaplan, and Haenlein 2012). Beberapa contoh media sosial yang kini popular digunakan dalam menjalankan bisnis online adalah Facebook dengan fitur Marketplace-nya, Instagram, Youtube, Whatsapp, line, Twitter, Telegram, serta website StartUp e-commerce seperti Shopee, Blibli, Tokopedia, Bukalapak, Go-jek, Grab, dan lainnya.

Namun, dalam menjalankan Bisnis Online, ada beberapa prinsip yang harus dipenuhi, antara lain keterbukaan (business practice disclosure) yaitu akan melakukan transaksi sesuai dengan yang dijanjikan. Integritas transaksi (transaction integrity) yaitu tagihan yang sesuai dengan transaksi juga sekaligus sebagai perlindungan terhadap informasi (information protection) yaitu penjagaan informasi agar tidak jatuh ke pihak yang tidak berkaitan dengan bisnisnya (Delerue, Kaplan, and Haenlein 2012)

Pelaku usaha saat ini telah banyak bermunculan, terutama dari kalangan anak muda. Tidak ada lagi 
ketakutan untuk memulai usaha, para pelaku usaha muda saat ini mengandalkan ide mereka, relasi serta sentuhan kreativitas untuk menjalankan usahanya (Rakib et al. 2020). Namun, semuanya menjadi berbeda saat Covid-19 menerpa negeri ini. Para pelaku bisnis muda ini tentu tidak siap dengan dampak yang terjadi, bukan hanyak para pelaku bisnis muda dan pemula, bahkan para pelaku bisnis lama yang lebih benyak mengandalkan kegiatan bisnis dan transaksi secara konvensional, banyak yang tidak mampu bertahan. Oleh karena itu, diperlukan adanya pengetahuan, pemahaman serta keterampilan dalam mengelolah usaha secara online. Mahasiswa yang merupakan para pelaku bisnis pemula sangat perlu dibekali pengetahuan dan keterampilan dalam mengolah dan memanaje usaha mereka secara daring (Syam et al. 2018).

Mencermati permasalahan tersebut di atas, diperlukan adanya pelatihan bagi para mahasiswa kelompok pebisnis pemula dalam memahami cara menjalankan bisnis secara online serta keterampilan dalam memanaje bisnis mereka secara daring dengan memanfaat berbagai media sosial dan fitur e-commerce yang tersedia. Kondisi pandemi ini pada dasarnya menjadi hantaman keras yang dirasakan oleh negeri ini. Kondisi perekonomian masyarakat meredup seketika bahkan hampir lumpuh. Namun, anak muda yang menjadi bagian dari generasi millennials harus menjadikan ini peluang besar dalam mengembangkan usahanya. Para generasi millennials saat ini menjadi pengguna aktif smartphone dan social media. Hal ini memberikan peluang pangsa pasar bagi pelaku bisnis sekaligus menjadi alat bagi mereka yang mampu menguasai bidang tersebut. Jika peluang ini dimanfaatkan secara maksimal, mahasiswa akan dapat memiliki penghasilan tambahan dalam membiayai kebutuahn sehari-hari mereka. Bahkan secara makro para pelaku UKM dari kalangan mahasiswa ini turut andil dalam membangkitkan kembali geliat roda perekonomian negara yang saat ini redup.

Berdasarkan kondisi tersebut, dapat diidentifikasikan beberapa permasalahan utama yaitu: Kurangnya pengetahuan dan keterampilan para pelaku bisnis pemula ini dalam mengelola bisnis secara online, kurangnya kreativitas dan inovasi dalam pemanfaatan media sosial dan berbagai starup e-commerce sebagai peluang bisnis ditengah Pandemi, pemasaran produk-produk yang dihasilkan masih banyak dilakukan secara offline dan konvensional sehingga daya jual produk mereka.

Adapun tujuan kegiatan ini agar peserta memiliki pengetahuan dan keterampilan dalam memanfaat social media serta fitur e-commerce dalam menjalankan bisnis mereka secara online. Selain itu, peserta diharapkan memiliki pemahaman pentingnya inoviasi dan kreatifitas dalam memanfaat teknologi dalam berbagai kondisi kehidupan. Adapun manfaat yang dapat dipetik dari kegiatan ini adalah peserta diharapan mampu merancang Bisnis Online dalam aplikasi media sosial seperti Youtube, Instragram, Facebook dan Whatshapp serta menggunakan berbagai fitur yang tersedia dalam mempromosikan produknya sehingga mampu memberikan keuntungan bagi usaha yang mereka jalankan.

\section{METODE YANG DIGUNAKAN}

Mitra dalam kegiatan pengabdian ini adalah kelompok komunitas pelaku bisnis pemula di kalangan mahasiswa Kota Makassar yang diikuti oleh 39 mahasiswa. Dalam kegiatan pelatihan ini para pelaku bisnis muda ini akan mendapatkan pelatihan dan sosialisasi mengenai pemanfaatan internet dan media sosial dalam berbisnis. Sehingga diharapakan dari pelatihan ini, para pelaku usaha muda ini memiliki wawasan, kreativitas serta inovasi dalam memanfaatkan teknologi khususnya internet sebagai sarana pemasaran produk dan transaksi bisnis terkhusus di tengah pandemi saat ini. Metode yang digunakan dalam penerapan IPTEKS ini adalah metode partisipatif (participatory learning) dengan menekankan pada prinsip learning by doing yang dikemas melalui tahap sosialisasi (ceramah), diskusi (sharing session), pelatihan dan pembinaan. Kelompok mitra diharapkan dapat berpartisipasi aktif dalam pelatihan bisnis online. 


\section{PELAKSANAAN DAN HASIL KEGIATAN}

Pelatihan ini dapat terlaksana dengan baik berkat kerjasama antara Tim pelaksana Dosen Jurusan Bisnis dan Kewirausahaan dengan Mitra yakni Fakultas Ekonomi Universitas Negeri Makassar. Partisipasi Mitra dalam hal ini diantaranya mendaftar dan mengkoordinir peserta yang ikut serta dalam pelatihan, membantu fasilitas sarana dan prasarana yang dibutuhkan dalam proses pelatihan.

Dalam kegiatan pelatihan ini menggunakan alat dan bahan yang digunakan untuk melaksanakan kegiatan ini. Adapun alat yang digunakan berupa Komputer PC, Laptop, Earphone, dan Sound System, serta perangkat-perangkat lainnya yang dibutuhkan dalam proses pelatihan secara daring ini. Bahan yang digunakan kertas kwarto untuk dipakai catatan sementara sebelum dipindahkan ke Laptop. Kertas Kuarto untuk laporan pengabdian, alat tulis menulis serta tinta printer untuk penggandaan laporan.

\section{1) Tahap Persiapan}

Survei dan observasi jenis usaha bisnis yang telah dijalankan atau digeluti oleh para peserta. Setelah mengetahui gambaran kondisi peserta, selanjutnya dailakukan pemantapan materi yang akan disampaikan. Penyusunan bahan/materi pelatihan meliputi: modul pelatihan dan slide presentasi pelatihan, serta Penyebaran Pamflet Pelatihan serta Link serta Password Room meeting.

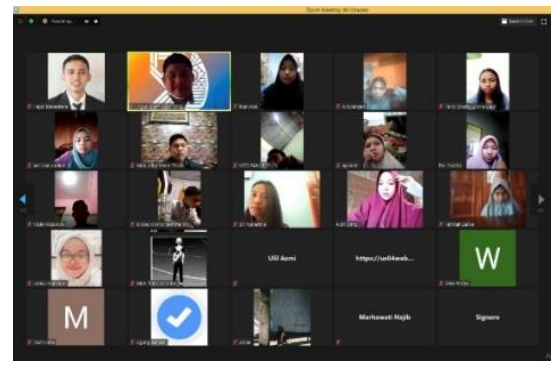

Gambar 1. Proses persiapan dan Registrasi Peserta

\section{2) Tahap Pelaksanaan Pelatihan}

Pada tahap ini peserta terlebih dahulu login menggunakan akun masing-masing, kemudian diverifikasi oleh admin. Selanjutnya dilakukan pelatihan serta pemberian materi berdasarkan hasil observasi oleh Tim Pengabdi. Pelatihan ini dilakukan dengan terlebih dahulu memberikan mengenai pentingnya bagi generasi muda terutama mahasiswa dalam mengikuti trend perkembangan teknologi dan informasi. Pelatihan ini juga memfokuskan pada pemberian kiat mengelola bisnis dengan teknik pemasaran secara daring, serta berbagai macam inovasi bisnis berbasis startup yang dapat dikembangkan oleh anak muda dalam masa pandemi. Simulasi dalam pelatihan ini dilakukan dengan mempertimbangkan jenis bisnis yang sedang dikelola oleh tiap peserta, kemudian dilakukan praktek serta sharing session dalam mengelola bisnis secara daring melalui berbagai platform media social seperti Instagram, Whatsapp, dan marketplace facebook serta website e-commerce.

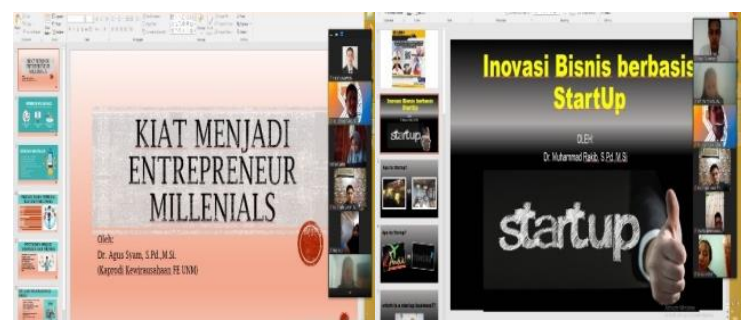

Gambar 2. Tim Pengabdi Memaparkan Materi dan Memberikan Penjelasan Teknis

Selanjutnya agar mahasiswa lebih memahami pelatihan merancang startup bisnis online, mahasiswa melakukan simulasi/praktik. pengenalan beberapa fitur dan web yang digunakan dalam menjalankan bisnis online

\section{3) Tahap Testing dan Sharing}

Penyampaian materi pelatihan dilakukan dengan ceramah kemudian dilajutkan dengan Tanya jawab bila masih ada hal yang belum dipahami oleh peserta. Tahapan testing ini digunakan untuk mengetahui jenis produk yang dimiliki peserta serta menentukan jenis applikasi yang tepat digunakan. 


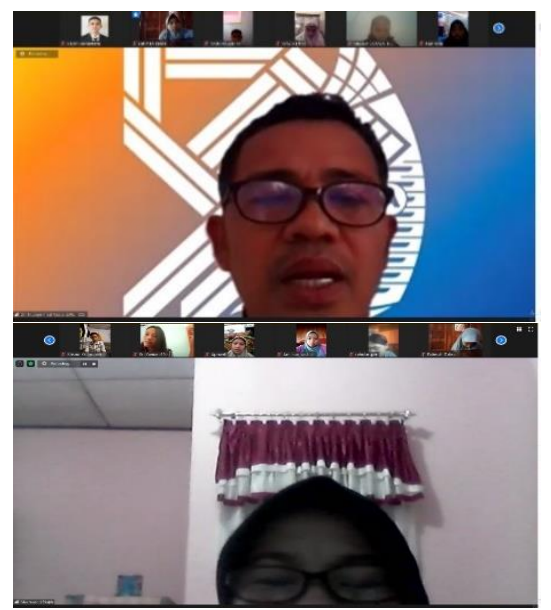

Gambar 3. Tanya Jawab dan Sharing dengan Peserta Pelatihan.

Jenis Produk dan beberapa media bisnis online yang dimanfaatkan oleh mahasiswa dalam memasarkan produknya:

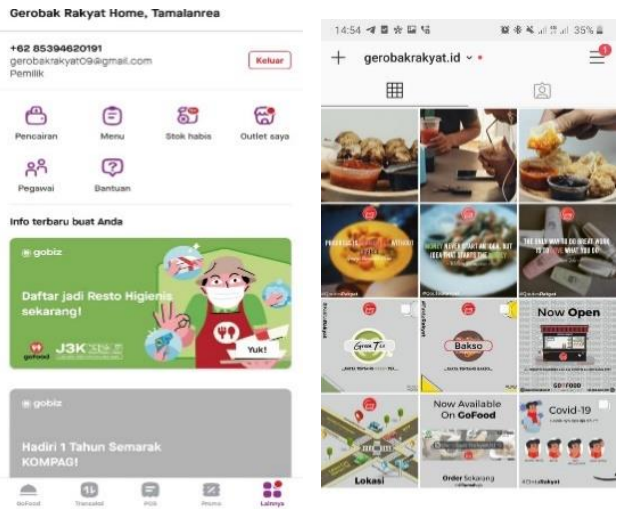

Gambar 4. Tampilan Bisnis Online Usaha Kuliner salah satu peserta Pelatihan, memanfaatkan media StartUp Go-jek.
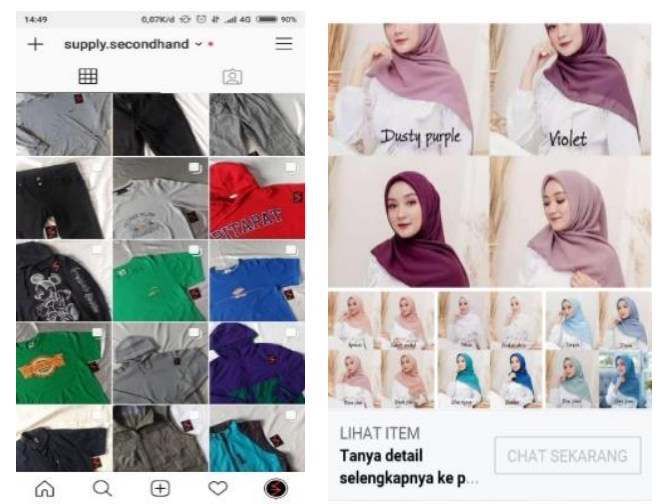

Gambar 5. Tampilan Produk Fashion milik peserta pelatihan yang memanfaatkan Media Marketplace Facebook dan Instagram sebagai media dalam memulai bisnis secara online.

\section{4) Tahap Evaluasi}

Pada tahap ini dilakukan kegiatan evaluasi untuk mengukur sejauh mana keberhasilan pelatihan yang telah dilakukan. Evaluasi yang dilakukan yaitu melihat tingkat partisipasi peserta dalam proses pelatihan dan tingkat keterampilan peserta dalam mengelola serta memanaj bisnis mereka secara daring.

Evaluasi aspek pelaksanaan pelatihan dilakukan dengan cara mengukur indikator keberhasilan yang meliputi, keterlibatan, kemampuan serta daya tangkap peserta selama pelatihan berlangsung. Peserta diharapkan dapat memahami manfaat serta cara penggunaan platform media social dalam menjalankan bisnis secara daring terutama di era Pandemi Covid-19.

Adapun tingkat partisipasi peserta dalam pelatihan ini sangat tinggi. Hal ini dapat dilihat dari tingkat kehadiran, keaktifan, kesiapan, inisiatif, dan kedisiplinan peserta selama proses kegiatan pelatihan berlangsung. Kegiatan yang dilakukan secara virtual ini menunjukkan antusiasme peserta sangat tinggi, dilihat dari sehari sebelum kegiatan dimulai sebanyak 35 peserta melakukan registrasi. Kedisiplinan serta kesiapan peserta juga sangat tinggi, hal ini terlihat Pada hari kegiatan pelatihan sebelum room meeting dibuka, mereka telah bersiap dan standby dihadapan perangkat masingmasing. Kehadiran serta keaktifan peserta juga sangat tinggi, terlihat dari proses pelatihan serta sharing dengan pemateri berlangsung lama dan komunikatif denga jumlah peserta yang bergabung sebanyak 39 peserta. Hal ini menunjukkan bahwa mahasiswa sebagai pelaku usaha muda memiliki partisipasi dan antusiasme yang sangat tinggi dalam mengikuti pelatihan merancang bisnis online ditengah kondisi pandemi.

Tingkat keterampilan yang dimiliki oleh peserta pelatihan setelah mengikuti ini dapat dilihat pada tabel berikut:

Tabel 1. Tingkat Keterampilan Peserta Pelatihan

\begin{tabular}{|c|c|c|}
\hline Variabel/Indikator & $\begin{array}{c}\text { Skor } \\
(\%)\end{array}$ & Kategori \\
\hline $\begin{array}{l}\text { Tingkat } \\
\text { Keterampilan/Penguasaan } \\
\text { IT }\end{array}$ & 78,29 & Terampil \\
\hline $\begin{array}{l}\text { - Jenis Usaha yang } \\
\text { kembangkan } \\
\text { - Kualitas Produk } \\
\text { - Pemanfaatan berbagai } \\
\text { platform jejaring media } \\
\text { sosial }\end{array}$ & $\begin{array}{l}73,08 \\
87,18 \\
74,62\end{array}$ & $\begin{array}{l}\text { Variatif } \\
\text { Berkualitas } \\
\text { Efektif }\end{array}$ \\
\hline
\end{tabular}

Tabel 1 di atas menunjukkan bahwa tingkat keterampilan peserta pelatihan bisnis online berada pada kategori terampil dilihat dari jumlah jenis produk yang dihasilkan beragam, produk yang 
dihasil berkualitas, dan pemanfaatan platform media sosial secara efektif dan kreatif.

\section{KESIMPULAN}

Hasil pelaksanaan kemitraan masyarakat dapat ditarik kesimpulan:

a. Peserta pelatihan telah memiliki partisipasi sangat tinggi dalam pelatihan bisnis online bagi mahasiswa yang terlihat dari kehadiran, keaktifan, kesiapan, inisiatif, dan kedisiplinan.

b. Peserta pelatihan sangat terampil dalam memanfaatan internet dan media sosial sebagai media bisnis online dilihat dari keragaman jenis usaha produk yang dikelola, kualitas, dan kreatifitas peseta dalam mendesain bisnis mereka melalui media sosial.

c. Peserta telah memiliki pemahaman tentang legalitas dalam bertransaksi online.

\section{UCAPAN TERIMA KASIH}

Ucapan terima kasih disampaikan kepada Rektor Universitas Negeri Makassar yang telah memberikan dana PNBP dalam melaksanakan pengabdian ini. Selanjutnya ucapan terima kasih disampaikan pula kepada Ketua LP2M UNM dan pimpinan Fakultas Ekonomi beserta staf yang telah memberi fasilitas dalam kegiatan PKM hingga selesai, dan kepada para peserta pelatihan yang senantiasa antusias mengikuti program ini hingga akhir pelaksanaannya.

\section{DAFTAR PUSTAKA}

Aco, Ambo, and Andi Hutami Endang. 2017. "Analisis Bisnis E-Commerce Pada Mahasiswa Universitas Islam Negeri Alauddin Makassar." Jurnal Teknik Informatika 2: 1-13.

Ardianti, Dhini, Winne Wardiani, and Latifah Adnani. 2016. "PKM Pemasaran Online Pada Usaha Sabun Herbal Di Kota Bandung." Prosiding Seminar Hasil Pengabdian Kepada Masyarakat.

Delerue, Helene, Andreas M. Kaplan, and Michael Haenlein. 2012. "Social Media: Back to the Roots and Back to the Future." Journal of Systems and Information Technology 14(2): $101-4$.

Denilia Atsiska Y, Aflit Nuryulia P, Anida Latifah,
Nuri Amriyatul K, Teguh Sutanto, M Guntur M. 2019. "PERAN MAHASISWA DALAM ADOPSI E-COMMERCE (Studi Kasus Pengusaha Olahan Jenang Kedunggudel Sukoharjo)." Seminar Nasional dan The 5th Call for Syariah Paper Universitas.

Djamaludin, Djamaludin, Aviasti Aviasti, and Otong Rukmana. 2016. "Peningkatan Kemampuan Usaha Kecil Menengah Di Wilayah Bandung Raya Dalam Pemanfaaatan Internet Sebagai Sarana Pemasaran Dan Perluasan Jangkauan Pasar." ETHOS (Jurnal Penelitian dan Pengabdian): 125.

Farell, Geovanne, Thamrin Thamrin, and Igor Novid. 2019. "Pelatihan Pemanfaatan Digital Marketing Dalam Pengembangan Pemasaran Dan Kewirausahaan UKM Pada Kota Sawahlunto." Suluah Bendang: Jurnal Ilmiah Pengabdian Kepada Masyarakat 19(1): 42.

Kaplan, Andreas M, and Michael Haenlein. 2010. "Users of the World, Unite! The Challenges and Opportunities of Social Media." Business Horizons 53(1): 59-68. http://www.sciencedirect.com/science/article/pii /S0007681309001232.

Rakib, Muhammad. 2015. "Effect of Industrial Work Practice and Family Environment on Interest in Entrepreneurship to Students of Vocational High School." Journal of Education and Vocational Research 6(4): 31-37.

\section{. 2020. "DETERMINANTS OF \\ ENTREPRENEURIAL INTENTION : EMPIRICAL STUDY OF STUDENT ENTREPRENEURS.” 26(3): 1-12.}

Syam, Agus, Sitti Hasbiah, Muchtar Yunus, and Haedar Akib. 2018. "Determinants of Entrepreneurship Motivation for Students at Educational Institution and Education Personnel in Indonesia." Journal of Entrepreneurship Education 21(2): 2651. 